\title{
A Survey of Data Mining Techniques for Smart Museum Applications
}

\author{
Shinta Puspasari ${ }^{1}$, Ermatita $^{2 *}$ \\ ${ }^{1}$ Department of Informatics, Universitas Indo Global Mandiri, Palembang, Indonesia \\ ${ }^{2}$ Department of Computer Science, Universitas Sriwijaya, Palembang, Indonesia \\ ${ }^{1}$ shinta@uigm.ac.id, ${ }^{2 *}$ corr-author: ermatita@unsri.ac.id
}

\begin{abstract}
This research aims to find out what data mining techniques are effectively implemented in museums and what application trends are currently being used to improve museum performance towards modern museums based on intelligent system technology. The review was carried out on a number of articles found in journals and proceedings in the 2004-2020 period. It is found that the majority of data mining techniques are implemented in museum virtual guide applications, recommender systems, collection clustering and classification system, and visitor behaviour prediction application. Data classification, clustering, and prediction technique commonly used for museum application. Collections with historical and artistic value contain a lot of knowledge making data mining an important technique to be included in various applications in museums so that they can have an impact on the achievement of museum goals not only in the fields of education and culture but also economics and business.
\end{abstract}

Keywords: Data mining, Smart museum, A review

\section{INTRODUCTION}

The museum stores a collection of objects of historical, artistic and cultural value. The museum exists to preserve the culture and history that existed in the past until its existence known by the future generation. The museum collection is an attraction for visitors to come to learn about it. The museum collection is valuable data that attracts visitors to come. Museum collection data can be in the form of document collections of pictures, text, objects, etc. contain information for visitors [1]. If the information presented to visitors is monotonous and not in line with expectations, visitors will not be interested in exploring the museum. Will not even recommend to their colleagues to come to or revisit the museum [2]. Therefore, modern museums are currently competing to change the business strategy to improve visitors experience [3] by adding a touch of information and communication technology in the digital era [4] one of which is by implementing data mining techniques for smart museum application.
Data mining is a technique that aims to extract important information used for specific purposes [5]. For museum applications, data mining extracts information from data held by museums for various purposes improving its performance including to explore visitors' interest in museum collections [6] which can be used to provide recommendations for visitors about museum exhibition, predicting the level of museum visits in a certain period so as to prepare for events that can increase visitor interest [7-9]. Using an artificial intelligence approach to implement interactive applications to collections [10] or augmented reality that allows visitors to interact virtually with collections so that it seems like they are in the past where the collection is located, as well as interesting games so that visitors do not get bored while in the museum [11]. Modern museums become an interesting place to study as well as travel [12], one of which is by utilizing applications based on data mining techniques [13].

In this paper, we will discuss a number of data mining techniques that have been implemented in museums with various application purposes. Based on the results of the review, it will be known what are data mining techniques for extracting information in museums to be utilized by museum management in museum management and served to museum visitors so that they can optimize the performance of the museum in terms of education, economic and business.

The rest of this paper is organized as follows: Section 2 provides a brief literature review; Section 3 discusses the methodology that was followed in this study; Section 4 presents the findings of the implementation of data mining technique for museum application; and finally Section 5 concludes the paper.

\section{METHOD}

\section{A. Review of Data Mining Techniques}

Data mining carried out to the various data set formats with general process stages as shown in Fig. 1 
[14]. The data set stored in the data warehouse will undergo a selection and preprocessing process at the beginning of the data mining stage in order to obtain information or knowledge extraction with minimum bias. The techniques used at each stage in the data mining process adjusted to the data format in the data warehouse.

In museums, collections are not only in the form of image documents but can also be in the form of text, spatial, and video, as well as various other data related to visitors and museum management, thus forming big data [15-16]. For that, data mining techniques need to be included in smart museum application accordance with the data to be extracted and the purpose of extracting information to be carried out [17]. For example, to predict visitor interest or classify museum collections. Both have different targets even though they use the same dataset. As a result, various data mining techniques have emerged that effectively implemented for various museum applications.

1) Association Rule: As the most mature and wide use technique in data mining, association rule reflects the correlation among data in dataset [18]. The association rule generates the association rules in dataset to find a minimum support and minimum confidence where the confidence and support of association rule represents the rule's effectiveness and reliability. The process contains two steps, finding the item with all the transaction supports greater than the minimum support and generating strong association rules based on frequent item sets finding that affect the performance of association rule[19]. Finding the best association is high cost process to meet the requirement in the dataset. Optimization on association rule has been proposed to improve its performance [19-21].

2) Decision Tree: This data mining technique has a tree-like structure where the top is a root and each leaf has an attribute value to be analysed while each branch represents the possible output. The structure is simple but reliable for processing multi-dimensional data [22] widely used for prediction and classification [23-25]. The challenge faced when using this method is the repetition process of optimum tree structure analysis based on certain conditions affecting application performance.

3) K-Nearest Neighbour: This technique looks for the closest distance between one data and a centroid so that it is included in a class. Euclidean, as in (1), or other distance measurements used as the basis for determining data classification. This method is widely applied for data classification and pattern recognition [26]. KNN is a high cost technique for have to find all the distances between data [27] and $\mathrm{K}$ the centroid to find out the closest distance that represents the similarity of the data to a certain group.

$$
d(x, y)=\sqrt{\sum\left(x_{i}-y_{i}\right)^{2}}
$$

where $d(x, y)$ is the Euclidean distance between $x$ and $y$.

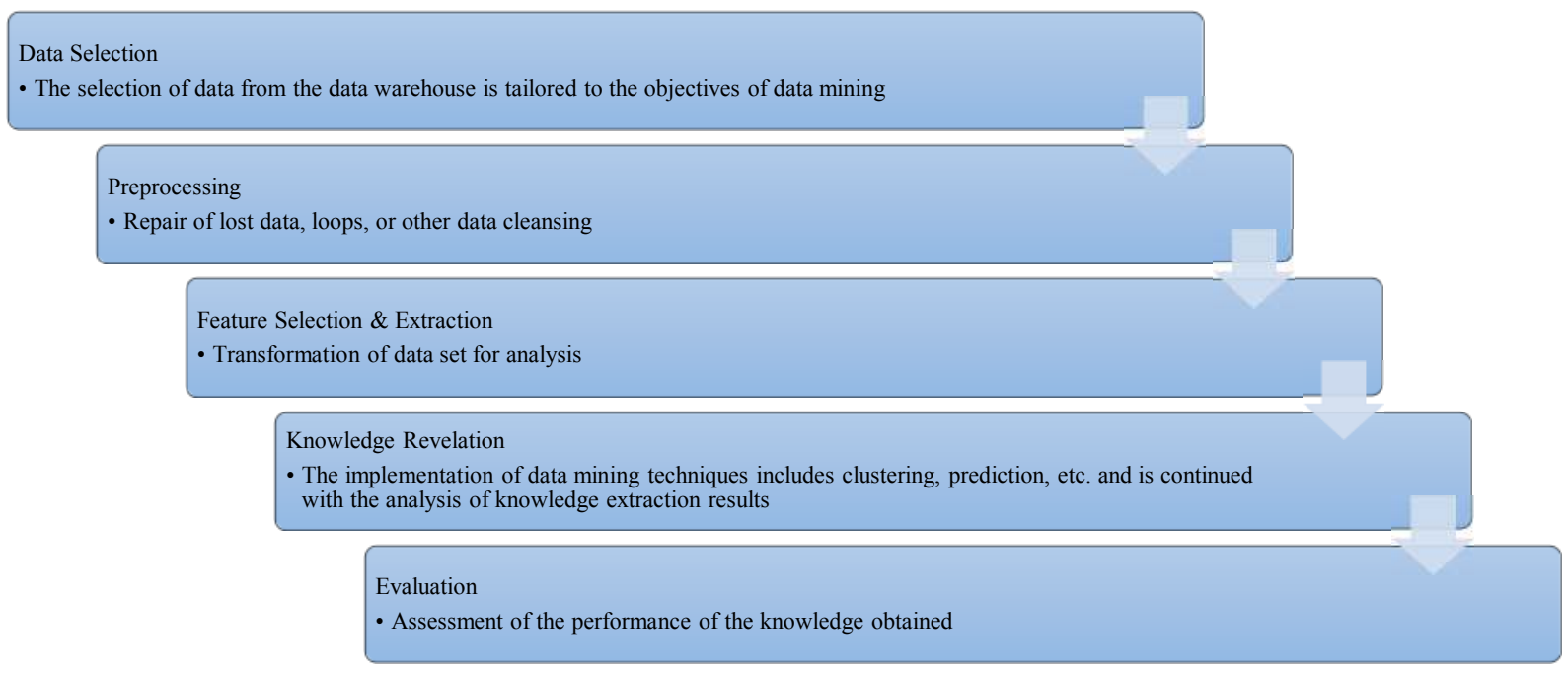

Fig. 1 Data mining process 
4) Hierarchical Clustering: The data grouped using a hierarchical approach to form a tree-like structure where each level of the tree will show a different group. One cluster can be decided to be separated or merged at a certain level based on the similarity criteria between the clusters are met. The agglomerative hierarchical clustering approach begins with separate data input which are grouped gradually to form a single group (bottom-up process) [28-29] while the divisive hierarchical clustering approach should be done in a top-down manner starting from one cluster which is separated into smallest element of the data set. Hierarchical clustering hybrid with other data mining methods for input optimization purposes [30].

5) Fuzzy Classifier: Fuzzy Classifier overcomes constraints on linguistic variables. By applying fuzzy logic this method is able to model uncertainty so as to form sufficient boundaries to separate data groups [31]. However, the constraints that arise due to the application of learning algorithms together with fuzzy logic cause high computation to become a challenge in the era of big data and industrial applications that demand accurate real time analysis results [32].

6) Artificial Neural Network: Artificial Neural Network (ANN) adopts biological neural workings that process input into output targets based on the learning process. Neural network architecture consists of a set of nodes located in connected layers and send signals to each other by various learning methods and algorithms. ANN has been proven its effectiveness for classification, pattern recognition, prediction in various other applications [33-35].

7) Support Vector Machine: Support Vector Machine (SVM) is a supervised learning method that is widely used for pattern recognition, classification and prediction of various fields of application, both text and image data [36]. SVM used for linear and non-linear data input transformed by certain methods and then look for a hypersurface of the input data set that is able to separate the data into two groups. SVM is effectively processing high dimensional space data with less time, for example in the text analysis process [37].

\section{B. Research Steps}

This study is a systemic literature review that provide evidence as the result of study [38]. The review tried to answer questions about data mining techniques applied to museum applications. Traditional museums that transformed into modern by adopting information and communication technology in museum operations combine with the application of intelligent systems promise a more interesting experience for visitors in exploring museums and improving museum performance [4]. This paper begins with a research question that must be clear, concise, focused, significant, feasible, and answer able so that each stage formulated for answering the research problems. The research stage begins with the formulation of the objective of reviewing and developing the dataset, then proceeding with a review process with a quantitative approach.

\section{1) Research Questions:}

Q1: What are the data mining techniques for museum applications?

Q2: What is the latest trend in museum applications implementing data mining techniques?

2) Development of Dataset: In this study, a data set was build containing a collection of articles on the search results of two data warehouses. The stages of developing the data set are as follows:

- Keywords Identification: Literature search on the database using inaccurate keywords will result in a very large data set so that it requires more energy to select the data obtained. The keywords in this study use the words "DATA MINING TECHNIQUE" AND "MUSEUM". The search method based on keywords was adjusted according to the search engine of each database used. To review the current state of research regarding data mining techniques related to the implementation of museum applications, a bibliometric mapping analysis was carried out with the VosViewer [39] tool. Based on the results of data processing, a visualization overlay is obtained as shown in Fig. 2. The bigger the circle the more publications regarding the term [40]. The word MUSEUM has a relationship with TERM DATA MINING TECHNIQE with the density seen from the color distribution and the size of the circle that represents the weight of the occurrence of words in the data set related to the above keyword. "DATA MINING" is related to the word "APPLICATION" and "SYSTEM" where the three of them are directly related to the word "MUSEUM". These results indicate that there are previous studies related to the application of data mining techniques in museums but with a small publication density compared to publications relating to museums in general. 
This research will carry out a deeper search to get the facts from the results of the analysis based on the results of the VosViewer processing.

- Database selection: In this study, Ieeexplore and Researchgate database were used with the consideration that Ieeexplore as one of the databases contains a collection of trusted and up-to-date publications while Researchgate contains a larger collection of free access for finding publication results relevant to the research objectives. Constraints arise when having to select the articles that were found one by one because the total number of retrieved documents is unknown and there are many publications that are not relevant for the purpose of the study. So for the research gate article from the top 500 results used as the initial data set. Meanwhile, Ieeexplore managed to find 87 documents relevant to the same given query "DATA MINING MUSEUM". A total of 587 articles formed the data set to then undergo the stages shown in Fig 3 and the review process.

- Articles Selection. At this stage, an assessment of the search result articles in both databases was carried out by conducting a quick review process of the titles and abstracts of the articles in the period of year 2004-2020 whether they were appropriate to this research question or not. The results of this stage are a dataset containing articles that are ready to be reviewed to answer research questions. The article selection process is carried out by taking a quantitative approach to the articles in the dataset that have been built according to the PRISMA used by [41] with steps such as Fig. 3 .

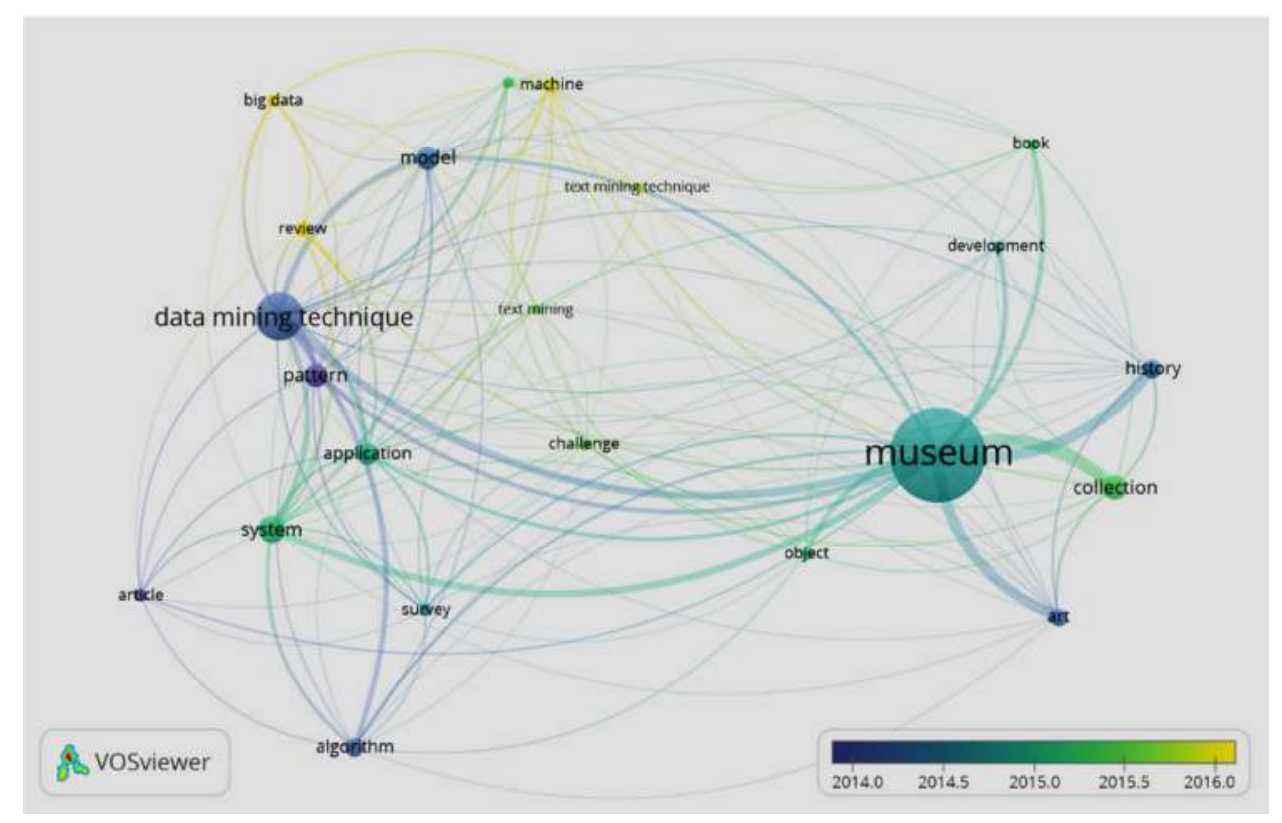

Fig. 2 Overlay visualization for keywords

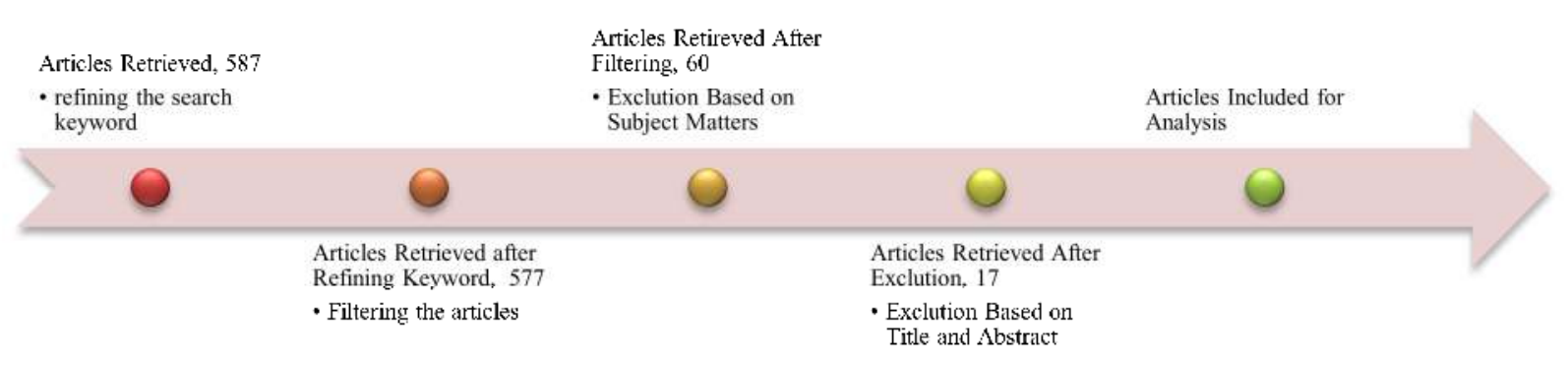

Fig. 3 Data set development phases for articles review 


\section{RESULTS AND DISCUSSION}

This study conducted a review of the extracted dataset from the Ieeexplore and Researchgate databases with the keyword "Data Mining Museum" as many as 17 articles were included for analysis on data mining techniques for museum applications and answered research questions $Q 1$ and $Q 2$ in this study.

\section{A. Trend of Museum Applications}

The museum is an institution that stores a collection of ancient objects of historical and cultural value. The mindset that museums must remain old-fashioned in order to maintain that identity is going to be abandoned along with the development of information and communication technology in digital era. The development of data mining applications in museums can be seen from the publications reviewed in this study in the period of year 2004-2020.

1) Distribution of Publication Years: A total of 17 articles in this research data set consisted of conference articles and journals in the period of year 2004-2020 with a portion of $24 \%$ of reputable international journals and $76 \%$ of indexed international conference proceedings. The distribution of publication years was grouped into two period, namely 2004-2010 and 20112020 with the percentage as shown in Fig. 4. Based on chart in Fig 4 it is known that the trend of developing museum applications with data mining has increased rapidly since 2010 . It is also known that $71 \%$ of scientific publications published in the last 10 years. This fact shows that data mining has technical improvement for museum applications, especially in the last 3 (three) years seen from articles published in journals in 2018.

2) Type of Dataset: The museum maintains a collection of historical objects including tools, paintings, books, photos which when they can be digitized in image, video, sound, and text formats. The results of literature review in this study show that the classification and catering process is carried out on digital museum collections and even creating a virtual museum for museum exploration by implementing data mining for text analysis for recommendations and prediction of visitor behaviour $32 \%$ using image data, $68 \%$ alphanumeric text data. Data in museums has even developed into big data for various analysis purposes as the virtual museum continues to develop following the development of the digital era [42].

3) Objective of the research study: The results of the analysis of the articles in the data set show that the application of data mining techniques in museums can be grouped based on the purpose of the application, namely virtual guide museums, collection classification and clustering system, recommender systems, and predictions of museum visitor behaviour. Interestingly, it is known that in the first period of publication of articles containing virtual guide applications, collection classification/ clustering, and visitor behaviour prediction, meanwhile the development of recommender system started in the second period. The distribution of the number of articles for the four categories of data mining applications in the museum is illustrated in Fig. 5, while the distribution per period for each category is shown in Fig 6. These facts founding answer Q2 research question, the trend of museum applications implementing data mining techniques. Recommender system and application for prediction visitor behaviour are the current trend of museum application. Most of them are used to mine the knowledge used for visitors to attract their engagement with museum and absolutely will affect museum performance.

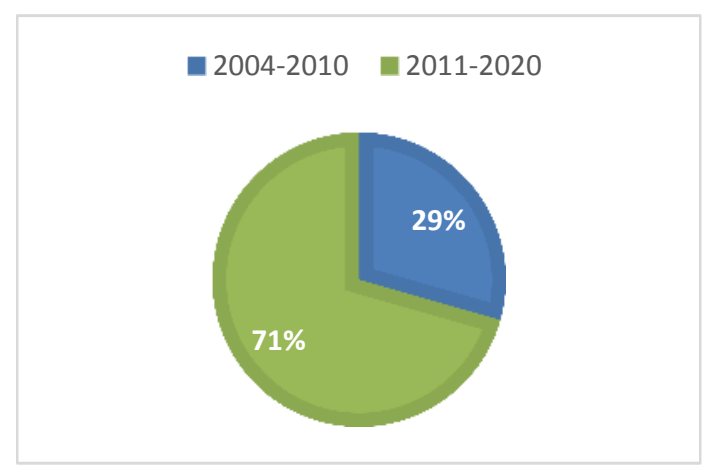

Fig. 4 Articles published per period of year 


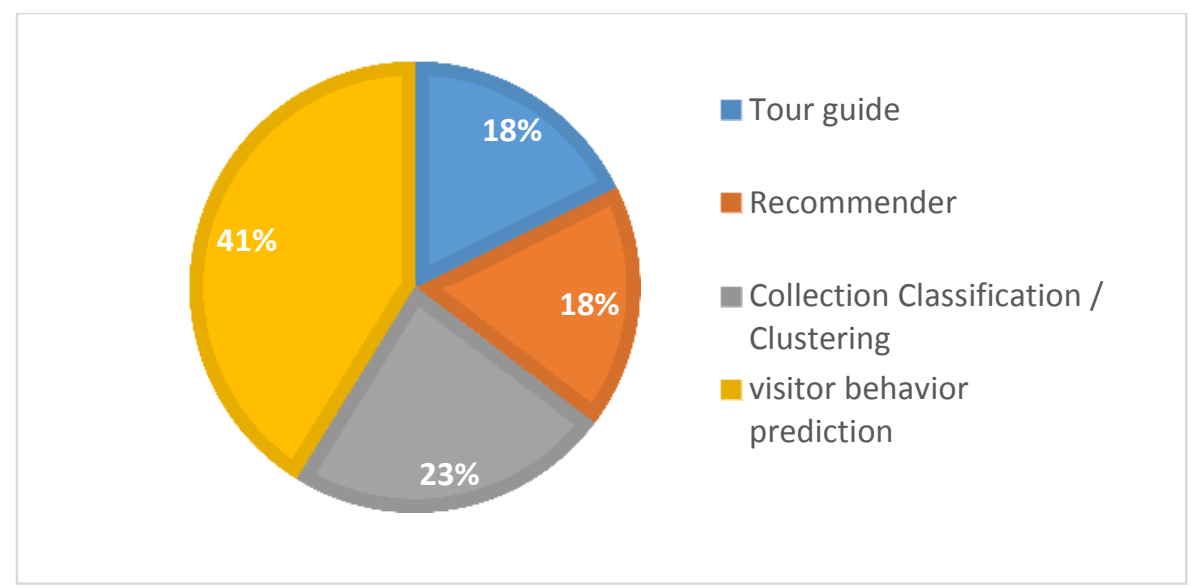

Fig. 5 Articles distribution of museum application

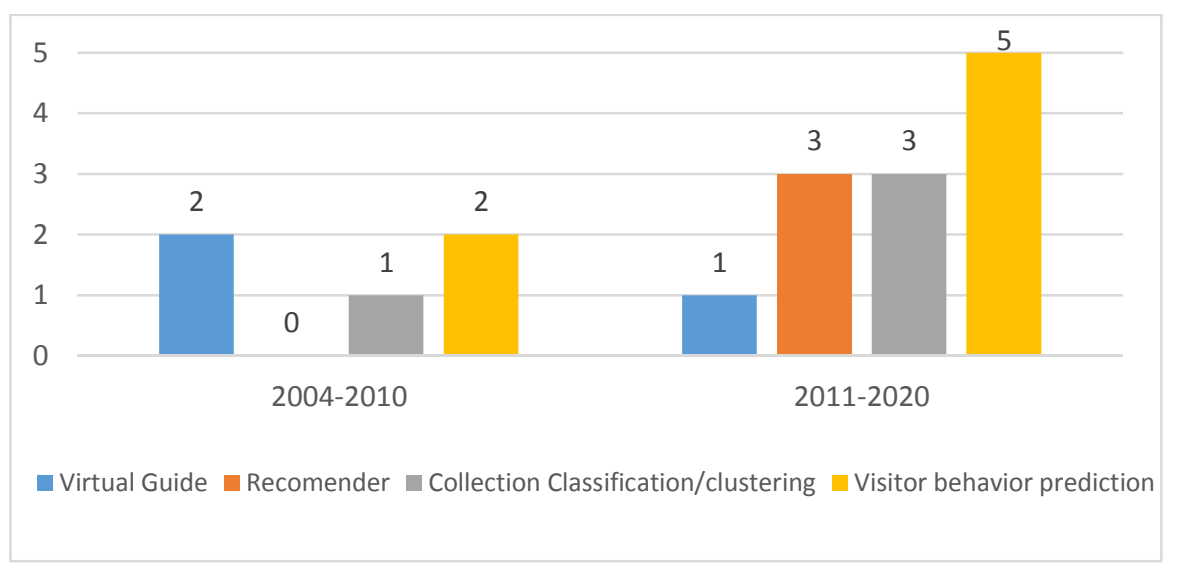

Fig. 6 Museum application cathegories distribution per periode of year

4) Data Mining Techniques: The research has succeeded in finding that the data mining techniques implemented for museum applications are Association Rule, Neural Network, Fuzzy Logic, Support Vector Machine, Hierarchical Clustering, K-Means, Nearest Neighbour, and some use a Hybrid approach of a number of data mining methods and other methods. Research question Q1 answered based on detail information in Table I.

\section{B. Challenge in Implementing Data Mining for Museum Applications}

The current trend of implementing data mining techniques in museums is the recommender system and visitor behaviour prediction application where $64 \%$ of articles during 2016-2020 period raised both of them as research topics. The purpose of implementing data mining in both application categories are to increase visitor interest in the museum, helping visitors to explore the museum exhibition easier, and also to manage the museum with regard to the arrangement of showrooms and museum collections that are in accordance with visitor interests, so that the museum is not only historical and cultural valuable but also economical and business.

The variety of visitor behaviour with various characters is a challenge for the museum to study for optimizing the role of the museum in the digital era. The rapid development of the internet today has demanded data mining techniques to be able to effectively processing big data, especially in museums with a high number of visits so that the extracted information can be used for modern museum management. Even though with the same collection, it can still attract visitors to revisit so that it will result in the formation of a big data set that can be optimized for its use by implementing information-based management strategies from the extraction of data mining applications [43]. 
TABLE I

ARTICLES REVIEW RESULTS

\begin{tabular}{|c|c|c|c|c|c|}
\hline Ref. & $\begin{array}{l}\text { Data Mining } \\
\text { Technique }\end{array}$ & Objective of Study & Data set & Museum Object & $\begin{array}{c}\text { Museum } \\
\text { Application }\end{array}$ \\
\hline [13] & Association rule & $\begin{array}{l}\text { To develop a tour guide system } \\
\text { that recommend the exhibits }\end{array}$ & $\begin{array}{l}60 \text { set of } \\
\text { Text data }\end{array}$ & $\begin{array}{lll}\text { Taipei } & \text { Fine } & \text { Arts } \\
\text { Museum } & & \end{array}$ & Virtual Guide \\
\hline$[44]$ & Association rule & $\begin{array}{l}\text { To promote acceptance of } \\
\text { content-based analysis for } \\
\text { designing a system of alternate } \\
\text { realities }\end{array}$ & $\begin{array}{l}\text { Not } \\
\text { mentioned }\end{array}$ & $\begin{array}{l}\text { The national museum \& } \\
\text { art gallery of New } \\
\text { Zealand, }\end{array}$ & Recommender \\
\hline$[45]$ & $\begin{array}{l}\text { The Neuro-Fuzzy } \\
\text { Classifier }\end{array}$ & $\begin{array}{l}\text { To classify visual arts image } \\
\text { collection }\end{array}$ & $\begin{array}{l}1007 \text { Visual } \\
\text { Arts images }\end{array}$ & Visual Arts collections & $\begin{array}{l}\text { Collection } \\
\text { Classification }\end{array}$ \\
\hline [46] & $\begin{array}{lr}\text { SparkML library } 7 \\
\text { and } & \text { machine } \\
\text { learning } & \end{array}$ & $\begin{array}{l}\text { To propose a novel user- } \\
\text { centered } \\
\text { strategy for cultural items } \\
\text { suggestion }\end{array}$ & $\begin{array}{l}473.289 \\
\text { cultural } \\
\text { objects }\end{array}$ & Not mentioned & Recommender \\
\hline$[47]$ & $\begin{array}{l}\text { K-Nearest } \\
\text { Neighbour, Support } \\
\text { Vector Machine }\end{array}$ & $\begin{array}{l}\text { To Classify 3D archaeological } \\
\text { artefacts based on a Multi-View } \\
\text { approach of curvature features }\end{array}$ & 1347 images & Templo Mayor museum & $\begin{array}{l}\text { Collection } \\
\text { Classification } \\
\text { system }\end{array}$ \\
\hline$[48]$ & $\begin{array}{l}\text { Bayesian Belief } \\
\text { networks and } \\
\text { Association Rule }\end{array}$ & $\begin{array}{l}\text { To Propose multilevel } \\
\text { classification techniques }\end{array}$ & $\begin{array}{l}\text { corpus on } \\
101 \text { pictures } \\
\text { of artefacts }\end{array}$ & Allahabad museum & $\begin{array}{l}\text { Collection } \\
\text { Classification }\end{array}$ \\
\hline$[10]$ & Association rule & $\begin{array}{l}\text { To proposed a personalized } \\
\text { guide recommendation system }\end{array}$ & $\begin{array}{l}\text { Not } \\
\text { mentioned }\end{array}$ & $\begin{array}{l}\text { Museum in Tainan } \\
\text { City, Taiwan }\end{array}$ & Recommender \\
\hline [49] & $\mathrm{CNN}$ & $\begin{array}{l}\text { To developed automated } \\
\text { classification of images online } \\
\text { collection }\end{array}$ & $\begin{array}{l}97.010 \\
\text { images }\end{array}$ & $\begin{array}{l}\text { The Metropolitan } \\
\text { Museum of Art }\end{array}$ & $\begin{array}{l}\text { Collection } \\
\text { Classification }\end{array}$ \\
\hline$[50]$ & $\begin{array}{l}\text { Classification } \\
\text { method used KNN }\end{array}$ & $\begin{array}{l}\text { To Classify Hand Gesture for } \\
\text { virtual museum }\end{array}$ & $\begin{array}{l}\text { hands } \\
\text { patterns }\end{array}$ & $\begin{array}{l}\text { E-Temple } \\
\text { museum }\end{array}$ & Virtual Guide \\
\hline$[8]$ & A nearest-neighbour & $\begin{array}{l}\text { To Classify the image for } \\
\text { museum guidance system }\end{array}$ & $\begin{array}{l}493 \text { video } \\
\text { captured by } \\
\text { user }\end{array}$ & $\begin{array}{l}\text { The City Museum in } \\
\text { Weimar }\end{array}$ & Virtual Guide \\
\hline [9] & $\begin{array}{l}\text { Regression and } \\
\text { graph for visitor } \\
\text { route }\end{array}$ & $\begin{array}{l}\text { To develop a device that } \\
\text { understand visitor's behaviour }\end{array}$ & $\begin{array}{l}12,944 \\
\text { visitors } \\
\text { devices }\end{array}$ & Louvre Museum & $\begin{array}{l}\text { Visitor } \\
\text { Behaviour } \\
\text { Prediction }\end{array}$ \\
\hline [51] & $\begin{array}{l}\text { Nearest-Neighbour } \\
\text { Collaborative Filter } \\
\text { and Gaussian Model }\end{array}$ & To Predict visitor behaviour & $\begin{array}{l}\text { pathways of } \\
158 \text { visitors }\end{array}$ & Melbourne Museum & $\begin{array}{l}\text { Visitor } \\
\text { Behaviour } \\
\text { Prediction }\end{array}$ \\
\hline$[7]$ & $\begin{array}{l}\text { Support } \quad \text { Vector } \\
\text { Machine }\end{array}$ & To Predict visitor behaviour & $\begin{array}{l}\text { Not } \\
\text { mentioned }\end{array}$ & $\begin{array}{l}\text { Chaiya national virtual } \\
\text { museum Thailand }\end{array}$ & $\begin{array}{l}\text { Visitor } \\
\text { Behaviour } \\
\text { Prediction }\end{array}$ \\
\hline$[52]$ & $\begin{array}{l}\text { Hierarchical } \\
\text { Agglomerative } \\
\text { Clustering }\end{array}$ & To Predict visitor behaviour & 182 visitors & $\begin{array}{l}\text { CoBrA Museum of } \\
\text { Modern Art }\end{array}$ & $\begin{array}{l}\text { Visitor } \\
\text { Behaviour } \\
\text { Prediction }\end{array}$ \\
\hline [6] & K-means & $\begin{array}{l}\text { To use the concept of K-Mean to } \\
\text { explore museum-motivated ideas } \\
\text { to enhanced understanding of } \\
\text { and insight into people }\end{array}$ & $\begin{array}{l}\text { Not } \\
\text { mentioned }\end{array}$ & $\begin{array}{l}\text { Dallas Museum of Art, } \\
\text { the San Francisco } \\
\text { Museum of Modern } \\
\text { Art, the Sports Legends } \\
\text { Museum }\end{array}$ & $\begin{array}{l}\text { Visitor } \\
\text { Behaviour } \\
\text { Prediction }\end{array}$ \\
\hline$[53]$ & $\begin{array}{l}\text { Hierarchical } \\
\text { clustering }\end{array}$ & $\begin{array}{l}\text { To Mine interesting patterns that } \\
\text { may define visitor behaviours }\end{array}$ & $\begin{array}{l}254 \text { visitors } \\
\text { data }\end{array}$ & $\begin{array}{l}\text { Hecht Museum in } \\
\text { Haifa, Israel }\end{array}$ & $\begin{array}{l}\text { Visitor } \\
\text { Behaviour } \\
\text { Prediction }\end{array}$ \\
\hline [54] & $\begin{array}{l}\text { Machine learning } \\
\text { for classification }\end{array}$ & $\begin{array}{l}\text { To Predict visitor behaviour to } \\
\text { explain the needs of different fan } \\
\text { groups }\end{array}$ & $\begin{array}{l}3,591 \text { posts } \\
\text { in museum } \\
\text { social media }\end{array}$ & $\begin{array}{lr}\text { British } & \text { Museum, } \\
\text { Musée du } & \text { Louvre, the } \\
\text { National } & \text { Palace } \\
\text { Museum } & \\
\end{array}$ & $\begin{array}{l}\text { Visitor } \\
\text { Behaviour } \\
\text { Prediction }\end{array}$ \\
\hline
\end{tabular}




\section{CONCLUSION}

This research is a literature study aims to find what data mining techniques are effectively implemented for museum applications and what application trends are built based on data mining currently used by various museums that have been published in articles and journals. Data collection from Ieeexplore and Researchgate databases with a selection process to obtain a data set. The dataset development process finally includes 17 articles of journal and proceeding published the period 2004-2020. The results of the review process on the dataset show that the commonly used data mining are the association rule, techniques for classification, clustering, including K-Means, KNearest Neighbour, Hierarchical, Neural Network, SVM, which are applied to the virtual guide system, recommender, collection classification/ clustering, and prediction of museum visitor behaviour. Recommender system and application for predicting visitor behaviour are the latest trend of museum application implementing data mining technique. The results of the research in this article indicate the application of data mining techniques effective in extracting information in the form of knowledge that is presented in a form suitable for the application's purpose in a museum and has increasing trend of implementation in museum application during last 3 years. The challenge in the future work is examining the effectiveness of data mining techniques for big data in museums considering the large number of museum collections and visitors with various cultural and character backgrounds will produce fast growing data set to be analysed and to produce information in the form of knowledge that can be used by modern museums.

\section{REFERENCES}

[1] S. Puspasari, "Design and Development of Information System for SMB II Museum Collection Management," International Journal of Advanced Science and Technology, vol. 28, no. 10, p. 8, 2019.

[2] J.-R. Chang, M.-Y. Chen, L.-S. Chen, and S.-C. Tseng, "Why Customers Don't Revisit in Tourism and Hospitality Industry?," IEEE Access, vol. 7, pp. 146588-146606, 2019, doi: 10.1109/ACCESS.2019.2946168.

[3] A. Orea-Giner, "Textual analysis as a method of identifying museum attributes perceived by tourists: An exploratory analysis of Thyssen-Bornemisza National Museum in Spain," Esic Market Economics and Business Journal, vol. 51, no. 3, p. 18, 2020.
[4] A. Carvalho and A. Matos, "Museum Professionals in a Digital World: Insights from a Case Study in Portugal," Museum International, vol. 70, no. 1-2, pp. 34-47, Jan. 2018, doi: 10.1111/muse.12191.

[5] S. S. Al-Rifai, A. M. Shaban, M. S. M. Shihab, A. S. Mustafa, H. A. Alhalboosi, and A. M. Shantaf, "Paper Review On Data Mining, components, And Big Data," p. 4.

[6] A. Krantz, R. Korn, and M. Menninger, "Rethinking Museum Visitors: Using K-means Cluster Analysis to Explore a Museum's Audience," Curator: The Museum Journal, vol. 52, no. 4, pp. 363-374, Oct. 2009, doi: 10.1111/j.2151-6952.2009.tb00358.x.

[7] K. Sriporn and C.-F. Tsai, "PREDICTING TOURISTS' BEHAVIOR OF VIRTUAL MUSEUM USING SUPPORT VECTOR MACHINE WITH FEATURE SELECTION TECHNIQUE," p. 6.

[8] E. Bruns and O. Bimber, "Mobile Museum Guidance Using Relational Multi-Image Classification," in 2010 4th International Conference on Multimedia and Ubiquitous Engineering, Cebu, Philippines, Aug. 2010, pp. 1-8, doi: 10.1109/MUE.2010.5575082.

[9] Y. Yoshimura, F. Girardin, J. P. Carrascal, and C. Ratti, "New tools for studying visitor behaviours in museums: a case study at the Louvre," p. 14.

[10] Y.-M. Huang, C.-H. Liu, C.-Y. Lee, and Y.-M. Huang, "Designing a Personalized Guide Recommendation System to Mitigate Information Overload in Museum Learning," p. 18, 2020.

[11] S. Puspasari, N. Suhandi, and J. N. Iman, "Enhancing The Visitors Learning Experience in SMB II Museum Using Augmented Reality Technology," in 2019 International Conference on Electrical Engineering and Informatics (ICEEI), Bandung, Indonesia, Jul. 2019, pp. 296-300, doi: 10.1109/ICEEI47359.2019.8988831.

[12] N. S. Podzharaya and A. S. Sochenkova, "The virtual museum development with the use of intelligent and $3 \mathrm{~d}$ technologies on the basis of the Maritime museum in Kotor,"p. 4, 2018.

[13] Y.-P. Huang and W.-P. Chuang, "Improving the Museum's Service by Data Mining and Location-aware Approach," p. 6.

[14] Anoopkumar M and A. M. J. Md. Z. Rahman, "A Review on Data Mining techniques and factors used in Educational Data Mining to predict student amelioration," in 2016 International Conference on Data Mining and Advanced Computing (SAPIENCE), Ernakulam, India, Mar. 2016, pp. 122-133, doi: 10.1109/SAPIENCE.2016.7684113.

[15] R. P. Kinsley and J. Portenoy, "Perspectives of Emerging Museum Professionals on the Role of Big 
Data in Museums," in 2015 48th Hawaii International Conference on System Sciences, HI, USA, Jan. 2015, pp. 2075-2084, doi: 10.1109/HICSS.2015.249.

[16] J. Li, L. Xu, L. Tang, S. Wang, and L. Li, "Big data in tourism research: A literature review," Tourism Management, vol. 68, pp. 301-323, Oct. 2018, doi: 10.1016/j.tourman.2018.03.009.

[17] W. Guo, Z. Huang, Y. Hou, Q. Xiao, J. Jia, and L. Mao, "Environment Parameter Rating Evaluation for Smart Museum Based on Improved K-Means Clustering Algorithm," Chinese Control And Decision Conference, p. 5, 2020 .

[18] Z. Li and R. Zhang, "The Association Rule Mining on a Survey Data for Culture Industry," p. 4.

[19] C. Song, "Research of association rule algorithm based on data mining," in 2016 IEEE International Conference on Big Data Analysis (ICBDA), Hangzhou, China, Mar. 2016, pp. 1-4, doi: 10.1109/ICBDA.2016.7509789.

[20] Y. Xi and Q. Yuan, "Intelligent Recommendation Scheme of Scenic Spots Based on Association Rule Mining Algorithm," in 2017 International Conference on Robots \& Intelligent System (ICRIS), Huai'an, Oct. 2017, pp. 186-189, doi: 10.1109/ICRIS.2017.53.

[21] Pan Qingxian, Qu Linjie, and Lou Lanfang, "Data mining and application of teaching evaluation based on association rules," in 2009 4th International Conference on Computer Science \& Education, Nanning, China, Jul. 2009, pp. 1404-1407, doi: 10.1109/ICCSE.2009.5228194.

[22] F.-J. Yang, "An Extended Idea about Decision Trees," in 2019 International Conference on Computational Science and Computational Intelligence (CSCI), Las Vegas, NV, USA, Dec. 2019, pp. 349-354, doi: 10.1109/CSCI49370.2019.00068.

[23] S. Hashemi, Ying Yang, Z. Mirzamomen, and M. Kangavari, "Adapted One-versus-All Decision Trees for Data Stream Classification," IEEE Trans. Knowl. Data Eng., vol. 21, no. 5, pp. 624-637, May 2009, doi: 10.1109/TKDE.2008.181.

[24] G. Yi-yang and R. Nan-ping, "Data mining and analysis of our agriculture based on the decision tree," in 2009 ISECS International Colloquium on Computing, Communication, Control, and Management, Sanya, China, Aug. 2009, pp. 134-138, doi: 10.1109/CCCM.2009.5267962.

[25] P. Chandrasekar, K. Qian, H. Shahriar, and P. Bhattacharya, "Improving the Prediction Accuracy of Decision Tree Mining with Data Preprocessing," in 2017 IEEE 41st Annual Computer Software and
Applications Conference (COMPSAC), Turin, Jul. 2017, pp. 481-484, doi: 10.1109/COMPSAC.2017.146.

[26] M. S. Aldayel, "K-Nearest Neighbor classification for glass identification problem," in 2012 International Conference on Computer Systems and Industrial Informatics, Sharjah, United Arab Emirates, Dec. 2012, pp. 1-5, doi: 10.1109/ICCSII.2012.6454522.

[27] I. Triguero, J. Maillo, J. Luengo, S. Garcia, and F. Herrera, "From Big Data to Smart Data with the KNearest Neighbours Algorithm," in 2016 IEEE International Conference on Internet of Things (iThings) and IEEE Green Computing and Communications (GreenCom) and IEEE Cyber, Physical and Social Computing (CPSCom) and IEEE Smart Data (SmartData), Chengdu, China, Dec. 2016, pp. 859-864, doi: $\quad$ 10.1109/iThings-GreenCom-CPSComSmartData.2016.177.

[28] H. Zhao and Z. Qi, "Hierarchical Agglomerative Clustering with Ordering Constraints," p. 5.

[29] Vijaya, S. Sharma, and N. Batra, "Comparative Study of Single Linkage, Complete Linkage, and Ward Method of Agglomerative Clustering," in 2019 International Conference on Machine Learning, Big Data, Cloud and Parallel Computing (COMITCon), Faridabad, India, Feb. 2019, pp. 568-573, doi: 10.1109/COMITCon.2019.8862232.

[30] D.-C. Park, "Hierarchical Clustering of 3-D Line Segments for Building Detection," p. 6.

[31] T. F. M. Raj, S. Meganathan, S. Indhumathi, and S. Jayanandini, "A fuzzy classifier approach using equivalence relations on faculty performance analysis," in 2017 International Conference on Computing Methodologies and Communication (ICCMC), Erode, Jul. 2017, pp. 888-891, doi: 10.1109/ICCMC.2017.8282593.

[32] M. Elkano, H. Bustince, and M. Galar, "Do we still need fuzzy classifiers for Small Data in the Era of Big Data?," in 2019 IEEE International Conference on Fuzzy Systems (FUZZ-IEEE), New Orleans, LA, USA, Jun. 2019, pp. 1-6, doi: 10.1109/FUZZIEEE.2019.8858943.

[33] A. Menon, S. Singh, and H. Parekh, "A Review of Stock Market Prediction Using Neural Networks," in 2019 IEEE International Conference on System, Computation, Automation and Networking (ICSCAN), Pondicherry, India, Mar. 2019, pp. 1-6, doi: 10.1109/ICSCAN.2019.8878682.

[34] S. Smetanin and M. Komarov, "Sentiment Analysis of Product Reviews in Russian using Convolutional Neural Networks," in 2019 IEEE 21st Conference on Business Informatics (CBI), Moscow, Russia, Jul. 2019, pp. 482486, doi: 10.1109/CBI.2019.00062. 
[35] P. S. Deshmukh, "Travel Time Prediction using Neural Networks: A Literature Review," in 2018 International Conference on Information , Communication, Engineering and Technology (ICICET), Pune, Aug. 2018, pp. 1-5, doi: 10.1109/ICICET.2018.8533762.

[36] S. M. Abdelmoneim, M. Kayed, and S. A. Taie, "A Comparative study for Feature Extraction and Classification of Images," in 2019 6th International Conference on Advanced Control Circuits and Systems (ACCS) \& 2019 5th International Conference on New Paradigms in Electronics \& information Technology (PEIT), Hurgada, Egypt, Nov. 2019, pp. 105-110, doi: 10.1109/ACCS-PEIT48329.2019.9062848.

[37] E. Laoh, I. Surjandari, and N. I. Prabaningtyas, "Enhancing Hospitality Sentiment Reviews Analysis Performance using SVM N-Grams Method," p. 5.

[38] S. Ahmad, N. A. Rosmadi, S. S. S. Ahmad, and S. A. Asmai, "Crowdsourcing for Requirements Engineering: A Simplified Review," p. 9.

[39] L. Setyowati, "Pengenalan Bibliometric Mapping sebagai Bentuk Pengembangan Layanan Research Support Services Perguruan Tinggi," JPUA, vol. 10, no. 1, p. 1, Oct. 2020, doi: 10.20473/jpua.v10i1.2020.1-9.

[40] A. Afiyati, A. Azhari, A. K. Sari, and A. Karim, "Challenges of Sarcasm Detection for Social Network: A Literature Review," Jurnal Informatika, vol. 8, no. 2, p. 169, Nov. 2020, doi: 10.30595/juita.v8i2.8709.

[41] M. Maphosa, W. Doorsamy, and B. Paul, "A Review of Recommender Systems for Choosing Elective Courses," IJACSA, vol. 11, no. 9, 2020, doi: 10.14569/IJACSA.2020.0110933.

[42] G. Papaioannou, "DOCUMENTING AND MINING MUSEUM BIG DATA: CHALLENGES ADDRESSED BY A NEW RESEARCH PROJECT IN QATAR," p. $10,2018$.

[43] G. Gaia, I. Ltd, J. P. Bowen, and A. Borda, "Museum Websites of the First Wave: The rise of the virtual museum," p. 9.

[44] S. A. ac nz Sigchi, "A Collective Intelligence Assessment Approach through Alternate Realities in 'The Museum of Gamers,"' p. 6.

[45] D. Neagu, S. Zhang, and C. Balescu, "A Multi-Label Voting Algorithm for Neuro-Fuzzy Classifier Ensembles with Applications in Visual Arts Data Mining," th International Conference on Intelligent Systems Design and Applications, p. 6, 2005.
[46] X. Su, G. Sperl1, V. Moscato, A. Picariello, C. Esposito, and C. Choi, "An Edge Intelligence Empowered Recommender System Enabling Cultural Heritage Applications," IEEE TRANSACTIONS ON INDUSTRIAL INFORMATICS, p. 10.

[47] M. Canul-Ku, R. Hasimoto-Beltran, D. Jimenez-Badillo, S. Ruiz-Correa, and E. Roman-Rangel, "Classification of 3D Archaeological Objects Using Multi-View Curvature Structure Signatures," IEEE Access, vol. 7, pp. 3298-3313, 2019, doi: 10.1109/ACCESS.2018.2886791.

[48] A. Kumar, U. S. Tiwary, and T. J. Siddiqui, "Combining Words and Pictures for Museum Information Retrieval," p. 6.

[49] S. Surapaneni, S. Syed, and L. Y. Lee, "Exploring Themes and Bias in Art using Machine Learning Image Analysis," p. 6.

[50] S. Sumpeno, I. G. A. Dharmayasa, S. M. S. Nugroho, and D. Purwitasari, "Immersive Hand Gesture for Virtual Museum using Leap Motion Sensor Based on KNearest Neighbor," in 2019 International Conference on Computer Engineering, Network, and Intelligent Multimedia (CENIM), Surabaya, Indonesia, Nov. 2019, pp. 1-6, doi: 10.1109/CENIM48368.2019.8973273.

[51] F. Bohnert and I. Zukerman, "Non-intrusive Personalisation of the Museum Experience," in User Modeling, Adaptation, and Personalization, vol. 5535, G.-J. Houben, G. McCalla, F. Pianesi, and M. Zancanaro, Eds. Berlin, Heidelberg: Springer Berlin Heidelberg, 2009, pp. 197-209.

[52] C. Martella, A. Miraglia, M. Cattani, and M. van Steen, "Leveraging proximity sensing to mine the behavior of museum visitors," in 2016 IEEE International Conference on Pervasive Computing and Communications (PerCom), Sydney, Australia, Mar. 2016, pp. 1-9, doi: 10.1109/PERCOM.2016.7456513.

[53] N. Juniarta, M. Couceiro, A. Napoli, and C. Raissi, "Sequence Mining within Formal Concept Analysis for Analyzing Visitor Trajectories," in 2018 13th International Workshop on Semantic and Social Media Adaptation and Personalization (SMAP), Zaragoza, Sep. 2018, pp. 19-24, doi: 10.1109/SMAP.2018.8501882.

[54] Y. Chen, W. Zhou, B. Cui, and Y. Tong, "The Impact of Social Media Emotions and Behavioral Participation on Destination Image: A Case of Museum Image Mining," in 2019 14th International Conference on Computer Science \& Education (ICCSE), 2019, pp. 590-595. 